The Geneva Papers, 2007, 32, (483-493)

\title{
Pension Reform in Poland
}

\author{
Aleksandra Wiktorow \\ Centrala Zakładu Ubezpieczeñ Społecznych, ul. Czerniakowska 16, Warszawa 00-701, Poland. \\ E-mail: Wiktorowa@zus.pl
}

\begin{abstract}
After an introduction comparing pension reforms in Poland and in the rest of Europe and the world, the article describes and analyses the Polish reformed old-age pension system and its prospects. As the general architecture of the system has now been determined, some important parts are yet to be decided, in particular the payment institution of the second pillar. The author points out some fundamental questions such as the adequacy of pension benefits, state guarantees, and gender inequalities that are connected with the new system and which need to be challenged.
\end{abstract}

The Geneva Papers (2007) 32, 483-493. doi:10.1057/palgrave.gpp.2510147

Keywords: pension reform; reformed old-age system in Poland; pensions and gender

\section{Introduction - mandatory funded pension systems in Poland and Europe}

For several years now there has been heated global debate on the necessity to reform the pension system. However, to date few countries have implemented such radical reform. The most advanced in reforms is South America, though it must be noted that the appraisal of the results of new, partially or fully funded pension systems, operational in some countries even for dozen of years or longer, varies from one country to another. In Europe, Central and Eastern European countries were among the first to start reforming their pension systems since they perceived in the previous insurance funding mechanisms the largest threat to public finances. In Hungary, Poland, Bulgaria and Romania, the mandatory double-pillar pension system was implemented with an essential constituent being a funded pillar. A comparable system was adopted in Russia in 2003. Baltic States such as Latvia, Estonia, and Lithuania also have in their universal pension systems certain elements of capital market insurance. In Western European countries, only Sweden changed radically in 1999 its pension system by introducing a mandatory funded pillar, and making the first-pillar dependent to a large extent on contributions collected earlier. Several other countries do not have universal and mandatory private pension funds. A limited funded pillar exists in Italy, and in 2003 a voluntary participation in funded pension insurance was introduced in Germany. In other countries - for example, the Netherlands, Switzerland - company pension schemes have become mandatory in parallel to minute changes in the basic state systems. Reforms of basic pension systems in Western Europe have been and will be very cautious; to date, they have focussed mainly on raising retirement age and on the gradual equalization of the retirement age of men and women. Meanwhile in CEE countries and in former Soviet republics, the reforms have been radical, although not yet completed in terms of introducing all the necessary institutions. Thus, it is hard to evaluate their outcome at this stage. 
The experience of both South America and countries in transition in Europe are very topical issues on the international forum. The experience related to the implementation of funded pension systems is watched carefully because of the possibility of global economic slowdown or a serious economic crisis (such as, e.g., in Argentina that has had such mandatory partly funded pension systems since the mid-1990s). During legislative efforts and during the presentation of new solutions to the general public the "propaganda" period - the advantage of a new system with individual savings elements over a single-pillar PAYG is emphasized. Only the practical learning of funded system operations in recession and unemployment will perhaps allow some of its components to be revised, or, at least, the way of presenting advantages and disadvantages of funded and PAYG pension benefits. Nobody questions that the PAYG system is sensitive to demographic changes and ageing of societies, but at the same time it is more immune to inflation and capital market turbulence. The individual nature of pension savings in funded systems eliminates to a great extent redistribution and allows to limit future subsidies to the social insurance system. However, a more radical curtailment of subsidies will be possible only when all pensioners collect their pension benefits from double-pillar, defined-contribution schemes. As long as some pensioners will be paid benefits under the old redistribution system, which contains as a rule redistribution elements, state budget subsidies will be indispensable. From the perspective of an individual's whole working career, the fact of being jobless or having limited earnings has almost the same impact on individual pension whether it is a redistribution or a funded pension system. Frequently the pinpointed advantage of the funded system over the redistribution system - the nonsusceptibility to political manipulation in the light of developments in South America and Central and Eastern Europe - is not fully justified. It can turn out that funded system rules, valid at a certain moment, are also sometimes modified, adapting to the economic and political needs of the state, as it has been the case with the redistribution system.

These remarks should not lead to the conclusion that it is necessary to withdraw from double-pillar systems, but rather that it is necessary to give a second thought to many issues connected with the system design. This necessity is confirmed by the exchange of experience at international conferences, especially those organized by the International Social Security Association (ISSA), focussing on the safety of mandatory funded pillars. It should be noted that in Europe we are still in the contribution collection phase in the second pillars of pension systems. Still, the rules for new pension benefits under this pillar are not completed (except for Sweden), and it is not yet known what kind of pension benefits will be paid and who will administer and pay them out.

\section{The Polish pension system reform}

\section{Transition period - both "old" and "new" pension systems are operational}

The analysis of the operational experience of the new pension system in Poland in the first 8 years of its operations showed that there is not an ideal system and that the planning itself will not substitute for practice. Therefore the design itself of the 
double-pillar pension system, and not only its implementation, is being questioned. The reform was launched in 1999.

Initially attention focussed mainly on implementation problems, and on the poor preparation of the institutions to perform new responsibilities, especially in the IT area. However, the difficulties were easily predictable, since it is not feasible to implement such a huge project within 1 month from its parliamentary bill enactment. The lawmakers should have taken this into account. These organizational problems had no impact on the system design itself and on the level of future pensions, though they are annoying to the general public and individual members of the insured who would like to know on a current basis the balance of their accounts kept by the pension funds. The conclusion is obvious - any changes so fundamental as the departure from a pension system funded on redistribution to a pension system with hybrid funding, with a parallel shift from defined-benefit scheme to definedcontribution scheme, have to be prepared perfectly. All institutional stakeholders must have time for organizational preparations, whereas necessary costs must be covered by the state budget not only in the first year of operation, but also in the subsequent years. Such transformation is not able to cover any social insurance institution using an insurance contribution (e.g., in Poland the operating costs of the Social Insurance Institution are covered from an appropriation from the contribution-based funds for individual types of insurance).

Switching even into a partially funded system results in the shrinking of current revenues used for current pension benefits payments. Before the reform, total collected contributions were used to cover current pension benefit payments. Once the reform was implemented, the persons born before 1948 were not covered by the reform and remained in the old defined-benefit pension scheme, and their old-age pension contributions (19.52 per cent of their wage) were transferred only to the Social Insurance Fund. The people born between 1949 and 1968 are covered by the reform, but their enrolment with second capital-pillar pension funds was voluntary. It must be admitted that approximately 70 per cent of people from this age bracket chose membership in the pension funds under the second capital pillar. The overall pension contribution (19.52 per cent) for the people who remained in the first redistribution pillar is transferred to the Social Insurance Fund. For the persons who decided to become members of pension funds under the second pillar, a part of their contributions (12.2 per cent of their wages) was transferred to the Social Insurance Fund, and another part (7.3 per cent) went to a selected open-ended pension fund. The people born after 1969 are mandatorily covered by the double-pillar pension system, so their contribution is divided as above. The source for bridging the deficit when a part of the contributions was redirected to the second pillar can be only state budget. The contribution to the second pillar in Poland is higher than in other countries that also introduced a mixed system with a capital component (e.g., in Sweden the contribution to the second pillar, with a pension system model being very similar, accounts for 2.5 per cent). It can be said that Poland made a conscious decision to incur high budgetary burdens over a period of several years or even several dozen years by allocating really substantial funds for refunding to the pay-as-you-go system to fill the loss caused by the outflow of contributions to the second pillar. In 2006, the required contributions in the second pillar accounted for almost half of the planned 
budget deficit. Such a high burdening of the budget with pension reform expenditures has a major impact on the capability to finance other needs, for example in the infrastructure area (e.g., roads). This illustrates that the social insurance system reform was assigned top priority.

\section{First pension pillar operations}

As mentioned above, each person born after 1948 is covered by the pension system reform. The new system is based on a contribution-defined scheme, in both the first and second pillars. However, the first pillar is still PAYG, whereas the second pillar is funded.

The first pillar is administered by the Social Insurance Institution. Every insured has an individual account on which the total amount of old-age insurance contributions paid monthly is recorded. The contributions are adjusted on a yearly basis with the inflation rate plus a real growth rate indicator of the contributions. The account of the insured who had worked before the reform shows also the individually calculated "initial capital" that reflects the contribution to the pension system before the reform. The initial capital was recorded as of 1 January 1999 and has been indexed since then like other contributions. The old-age pension is calculated as follows: the sum of collected, indexed contributions and initial capital is divided by the average further life expectation in months specific to retirement age. The average further life expectancy taken into account here is the same for men and women. Such a decision was taken, despite the fact that retirement age remained different for both genders (60 years for women and 65 for men). Retirement is not compulsory at a specific age, the retirement age is the minimum age for retirement.

One has to retire under both pillars simultaneously. It is vital due to the minimum old-age pension guarantee. Only persons who have paid contributions for at least 20 years for women and 25 years for men are eligible for the minimum pension. If the above conditions have been met and the total old-age pension payable under the first and second pillars is lower than the statutory minimum, then the benefit amount is raised to the minimum old-age pension, which is financed from the state budget.

\section{Second pension pillar - contributory period}

From the perspective of the insured the protection of their interests is crucial. All operational principles of the second pillar where only private institutions operate are regulated by law. The contributions payable under the second pillar are transferred to the open-ended pension funds managed by the universal pension companies. The management of contributions may represent their sole activity. One pension company is allowed to manage one fund only. Thus the capital adequacy requirements are specified for the institution that wants to undertake such activity, its statutes are examined, and management fee principles and investment caps are defined. To a certain extent, the assets on an individual account of each member of open-ended pension funds are also protected. The second-pillar contribution accounts for 7.3 per cent of the wage and is paid by the employee. However, the contribution is calculated, 
deducted from the wage, and transferred to the Social Insurance Institution by the employer. The Social Insurance Institution checks if the contribution has been calculated correctly, carries out enforcement procedures vis-à-vis the employer if necessary, keeps records of paid contributions on a special account, and then, later, transfers the contributions to the open-ended pension fund selected by the insured.

The allowable investment structure for the pension funds under the second pillar cannot be overestimated. The capital markets in each country have a certain capacity and this has to be borne in mind when planning contribution levels. In Poland, monthly inflows of funds to the open-ended pension funds are so high that they determine the stock exchange situation (though the investments into stock of listed companies may not exceed 40 per cent of funds' assets). Thus, voices are being heard that it would be necessary to amend investment caps, widen investment options in foreign markets, and adopt new financial instruments.

The total assets of open-ended pension funds have been growing very fast: while in 1999 they amounted to PLN 2248 million, in April 2007 the total assets amounted already to PLN 130022 million. Such high growth rate is fuelled not only by high amounts of contributions paid under the second pillar but also by good investment performance. A total of 36-month rates of return in the last 6 years have hovered around approximately 50 per cent.

The insured is protected against the loss of assets by a minimum rate of return mechanism. The minimum rate of return is a rate of return lower by 50 per cent than the average rate of return for all pension funds in the same period or lower by 4 percentage points than the average, whichever value of the two is lower. The deficit occurs in the fund if its rate of return for the period of 36 months is lower than the minimum required rate of return. When such deficit has occurred, it is covered by a depositary, provided that the deficit is due to the loss of physical assets. Otherwise the company managing the fund is held responsible for the loss of funds and the deficit is covered using the fund's reserve account. If the reserve fund is insufficient then the deficit is covered by the Guarantee Fund, to which all pension funds active in the market have to contribute. However, the pension fund that has used the assistance of the Guarantee Fund is declared bankrupt, and its assets and members are taken over by the pension fund with the highest rate of return.

In the last 8 years, the legislation on second-pillar operations has been amended many times. The amendments were the outcome of experience gathered by many market players in the second pillar of pension funds in Poland, viz. open-ended pension funds, supervision over second-pillar pension funds (its organization was changed twice, currently the oversight is exercised by the Financial Supervision Committee dealing with the overall capital market), the Social Insurance Institution and, finally, the most interested stakeholders, that is, the members of open-ended pension funds. Another objective was to reduce costs of management.

The management fee was reduced, which is a good example of the curtailment of administrative costs of open-ended pension funds. At present, administrative costs hover around 8 per cent given that a certain part of administrative costs connected with second-pillar service infrastructure is borne by the Social Insurance Institution a state body collecting contributions for open-ended pension funds from contribution 
payers and transferring them on behalf of insured individuals to the pension funds selected by them.

The administrative costs of open-ended pension funds (apart from their own costs) include:

- fees payable to the Social Insurance Institution for the collection of contributions from the insured, keeping individual records of them and their transfer;

- contributions to the compulsory Guarantee Fund;

- fees for supervision operations;

- compulsory reserve account of each fund;

- transfer agent fees and depositary fees;

- charges for correspondence sent to fund members once a year by registered mail.

Despite the statutory reduction of fees and charges, the pension companies managing the open-ended pension funds have the highest revenues in the Polish financial market. This is due to the fact that the assets under their management are growing rapidly, and the assets are not diminishing as the first persons who will retire (in small numbers in the beginning) will withdraw the collected funds only in 2009.

An important feature of the second pillar in the period of contribution collection until retirement is that the collected funds are to be inherited after the death of the fund's member. Also in case of divorce the funds are part of assets to be divided (unless the spouses established division of marital property); however, they may not be paid out in cash, but rather are transferred to the spouse's account to be used for future old-age pension. Such a mechanism of contributions' inheritance does not exist in the first pillar.

At the onset of reform there were 21 pension funds. At present, the number of pension funds is 15 and further mergers and acquisitions are expected. There have also been changes of owners. The largest pension fund has 21.1 per cent of the total number of members (2.7 million people), the second largest fund has 19.7 per cent, and the third one has 15.3 per cent. All remaining pension funds have less than 8 per cent market share, and the smallest fund has less than 2 per cent of the total number of members.

\section{Old-age pensions under the second pillar}

It has been already 8 years since the launch of the reform. Still, only now -2 years before the payment of first old-age pensions under second pillars - has a major debate on the design of old-age pension benefits been initiated. No consensus on this issue has been reached yet. At present, a draft act on funded old-age pensions paid by old-age pension insurance institutions is being discussed. It proposes the following solutions:

- three kinds of old-age pension under the second pillar are possible - individual lifetime annuity, marital old-age pension, old-age pension with a 5-year guaranteed period;

- old-age pension insurance institutions to be established will have to meet, inter alia, certain financial requirements. Such institutions have to be privately owned, 
established by life insurance companies, but there will be also one state institution, administered by the Social Insurance Institution;

- one-off management fees are defined in percentage terms. They are charged at the time of funds withdrawal from the open-ended pension fund and when becoming a member of the insurance institution (in order to protect the level of old-age pension);

- in order to reduce administrative costs no individual acquisition will be allowed; all old-age pension insurance institutions will prepare product information using the same template, then such information will be disseminated in the same manner to all retiring workers in a certain year who will select the product and insurance institution by filing an application with a selected institution. The insurance institution may not refuse to sign an agreement with the future pensioner;

- retiring workers who have failed to select an insurance institution will be allocated to the state-owned insurance institution;

- to calculate the level of old-age pension proposed for a certain year the average life expectancy tables prepared by the Polish Central Statistical Office do not have to be considered; however, such tables may be modified (with percentage limits for such modification being defined). It has not been decided yet if life expectancy tables are supposed to be the same for men and women or separate for each gender;

- the oversight over the operations of old-age pension insurance institutions will be always exercised by the Financial Supervision Committee (even if the life assurance company is foreign and is subject to supervision in the country of origin);

- the old-age pensions from pension insurance institutions will be paid via the Social Insurance Institution along with the old-age pensions under the first pillar. It is necessary in case the old-age pension has to be supplemented to the level of minimum old-age pension and will limit costs of transfer. The amounts of old-age pensions under the first and second pillars will be itemized.

We have listed major points of the draft act - and they stir a lot of emotions. There is no consensus about the number and design of products. The only unquestionable product is individual life annuity. The legitimacy of setting up a state-owned pension insurance institution is questioned because some critics claim that it will be subject to unfair competition since, unlike private insurance institutions, it is not a for-profit organization. On the other hand, some people emphasize that some elderly people would prefer a state-owned pension insurance institution since they trust the State more than private institutions; they believe that the risk of bankruptcy of the stateowned pension insurance institution is lower. The level of benefits over time is uncertain. It is not clear whether the benefits will be indexed and whether there will be any share of profits of the pension insurance institution.

As can be seen, the phase of designing old-age pensions under the second pillar is still in its early stages. It is disturbing to notice that only one year and a half is left to prepare the institutional framework and it cannot be assumed beforehand that legislative efforts will be short; the subject is difficult and parliamentary debate will also take some time.

To make things worse, in the 2009-2014 period only women will retire under the new scheme. This is a result of leaving different retirement ages for men and women. 
Women born in 1949 will reach retirement age (60 years of age) in 2009, and men born in 1949 will reach retirement age (65 years of age) in 2014. Only a small percentage of the oldest women are enrolled with open-ended pension funds; in further years their number will range from 5 to 20 thousand. The costs of setting up the pension insurance institution will be high (high capital adequacy requirements and other requirements proposed in the act), and there is no guarantee that in the initial period many women will choose a certain institution. It can be assumed that in the initial couple of years the pension insurance institutions will be always in the red, which may not be acceptable for the shareholders. Therefore they may plan to set up a pension insurance institution only when men will be of retirement age. Additionally, the deficit in the initial period may be deepened by the possible application of joint further life expectancy tables for men and women. This will lead to the situation where women's old-age pensions will be higher than those derived on the basis of women's life expectancy tables, and they will not be offset by the lower old-age pensions of men that will not be present in the portfolio yet.

If the act is not enacted by the end of this year, perhaps some transitional solution will have to be applied, which in turn seems to constitute an unconstitutional arrangement. It does not seem to be feasible either to pay women in the initial period of 5 years, some temporary old-age pensions to be recalculated as final only later.

\section{Other problems of the Polish pension system reform}

Only the major characteristics of the two compulsory pillars of the pension system were discussed above. In addition to compulsory schemes, there are also opportunities to save for one's old age under the third pillar. The lawmakers decided on two methods for such savings: the "group" savings - Employee Pension Schemes - and the "individual" savings - Individual Pension Accounts. The Employee Pension Schemes are established by the employer who pays contributions for employees, with a limit and an authorized organizational design of the scheme. For the insured who open for themselves an Individual Pension Account, the annual tax deductible limit for the contribution was established. These two auxiliary methods of saving for old age are not yet very popular. Statutory changes are planned to make these saving methods more attractive for both employers and employees.

It is important to raise a few crucial issues related directly and indirectly to the pension system reform. In 1998 when the acts regulating drastically new operational rules for the scheme were enacted, it was announced that, effective from 2007, there would not be early retirement benefits any longer; these benefits have been widespread in Poland and are enjoyed by many occupational categories and by all women. However, in the meantime, no efforts were made to define a list of employment positions that would be eligible to bridge old-age pensions. These types of "temporary" old-age pensions were supposed to be offered to people who, due to psychophysical reasons, are not able to perform their jobs until they have reached statutory retirement age. Employers and the state budget were supposed to pay additional contributions that would be transferred to a separately established fund for financing such "old-age pensions". Once retirement age is reached, the old-age pension would be calculated under the universal first and second pillars. However, the delay of 
work on bridge pension benefits hampered the drafting of the list of entitled persons. At the implementation date of the pension reform, it would have been much easier to have such a list, since it would have been implemented on a stock basis. Now, after this delay of 8 years, it is tougher to implement this regulation because nobody wants to give up earlier privileges, in particular coal miners who managed to secure their highly privileged position. At present, an attempt has been made to convince other occupational categories to give up their claims. In any case, all rights to earlier retirement benefits are to be liquidated for people born after 1968. The bridge pension benefits are currently the toughest regulatory issue and the most socially sensitive at the same time. However, if this issue is not addressed successfully, the social insurance system reform objectives will not be met entirely.

Solutions for the calculation base for disability pensions and family allowances are also missing, since to date only the old-age pension benefits have been reformed, whereas other derivative benefits were left to be reformed afterwards. The levels of disability pensions and family allowances have to match the level of new old-age pension benefits. These are not as difficult issues as the others, but they require statutory changes prior to 2009, that is, the year of payment of the first old-age pension benefits under the new scheme.

\section{Conclusions for further debate on the role of government in the double-pillar system, especially under the contribution-defined scheme}

The issue of operating costs of the new scheme has been discussed at length, because during national and international debates the issue of the pension system individualisation is frequently raised; the concept is that everybody contributes and collects for him/herself and only for him/herself, without any redistribution. In Poland, Sweden, and in many other CEE countries it was assumed in both pillars that future old-age pensions should be a result only of the total contributions gathered during one's lifetime.

Given the above, a question arises as to whether it is necessary to regulate the second-pillar operations so meticulously. Perhaps the state intervention in designing the new system in details has been too large, since the State does not have to guarantee payments in the future the way it had to under the benefit-defined PAYG system. Perhaps the scope of supervision is too wide and the responsibilities imposed on various public stakeholders in the pension system are too numerous. The share participation probably boosts costs a great deal, without providing enough protection to the future pensioner. However, a lot of Polish and foreign social insurance experts do not agree with such stance.

To sum up Polish issues with the pension system reform it must be noted that the range of proposed changes, without any doubt necessary to improve the design of open-ended pension funds, does not touch the heart of the matter, that is, fundamental questions about:

- the level of benefits under the contribution-defined system;

- the degree of investment risk borne by the system participants since it is a statutory obligation to participate in the funded pension; 
- the operation of the system equity principle: "the more collected contributions, the higher the pension" - under the circumstances where pensions will depend to a large extent on profits generated (or not) by the fund rather than by paid contributions;

- the readiness of the customers to accept venture capital funds - in the name of maintaining the level of pension benefits offered under the old system at the most;

- readiness of the funds' customers to accept the fact that in the mandatory funded pension scheme, being part of a mandatory social security system, differences in the level of future pension benefits can be significant (despite payment of identical contributions), depending on the rate of return generated by individual open-ended pension funds and funds management by the pension insurance institutions during the pension benefit drawing period;

- readiness to accept important differences between pension benefits of men and women, driven by different retirement ages and acceptance of minimum benefits.

Further efforts to improve the double-pillar system in Poland - mixed pay-as-yougo and funded pension schemes - will have to consider the above aspects, though in fact today time is running short. I believe it is the right place to quote here Mr. Nicolas Barr from the London School of Economics and Political Science who, in his numerous papers on these issues, noted that the thesis according to which the implementation of private pension systems may exempt governments and national budgets from any commitment is not supported any longer. The role of government in the proper operation of the private systems is more and more recognised. It is not true anymore that political pressure is exerted on the government only when it is necessary to meet obligations under the state pay-as-you-go pension system.

The higher the proportion of retirement income coming from private pension schemes (in Poland compulsory), the higher the pressure on governments to intervene and save the private system in face of a possible collapse. Today Poland is not threatened by such situation; however, if numerous early-retirement privileges continue to be maintained, and if retirement ages of men and women are not equal, then the situation of the future financial condition of the pension system may become difficult and consequently, the achievement of reform objectives.

The expectation of state guarantees for the customers - members of the open-ended pension funds - and pensioners - members of the pension insurance institutions triggers the need for a real state oversight over these institutions whose activities, as a rule, the customers are not able to monitor effectively themselves.

\section{Background reading}

Barr, N. (1993) The Economics of the Welfare State, London: Weidenfeld and Nicolson.

Golinowska, S. (2000) Dekada polskiej polityki społecznej [The Decade of the Polish Social Policy], Warsaw: Instytut Pracy I Spraw Socjalnych [Institute of Labour and Social Studies].

Holzman, R., Orenstein, M. and Rutkowski, M. (2003) Pension Reform in Europe: Process and Progress, Washington, DC: The World Bank.

Holzman, R. and Palmer, E. (eds.) (2006) Pension Reform, Issues and Prospects for Non-Financial Defined Contribution (NDC) Schemes, Washington, DC: The World Bank.

Zukowski, M. (2006) Reformy emerytalne $w$ Europie [Old Age Pension Reforms in Europe], Poznan: Akademia Ekonomiczna w Poznaniu [Economic Academy in Poznan]. 


\section{About the Author}

Aleksandra Wiktorow has been working in social security for many years, both in research and in administration. She held the post of Vice Minister in the Ministry of Social Policy in the early 1990s. She is currently Senior Researcher at the Research Institute of Market Economy and Professor as well as Chair of the Insurance Department in the Academy of Finance. 